\title{
The Effects of Recession: Cases of Lithuania and Ukraine
}

\author{
Jadvyga Ciburiene, Kaunas University of Technology, Tatiana Orekhova, Doneck State University
}

\begin{abstract}
The aim of this research is to describe and analyze the main effects of economic development after the recent financial crisis in Lithuania and Ukraine, which is one of economic cooperation partners of Lithuania. The article analyzes structural changes of economic activity in the countries (agriculture, industry, services) and the changes of the main macroeconomic indicators, gives classification of recession effects according to different criteria (factors causing them, time factor, the structure of economic activity).
\end{abstract}

Keywords: contraction of economy, economic development, effects of recession, labour force.

\section{INTRODUCTION}

Since the financial crisis in 2008, all countries in the world have experienced a deep economic downturn, as shown by the main macroeconomic indicators. The ongoing contraction of economy increases the unemployment levels and decreases general price levels. An unemployed person loses all or a share of income, health insurance, moreover, some psychological issues arise and overall health is affected. Qualified and competent workforce is often the key factor in ensuring competitiveness, increasing the attractiveness of the region. Experience shows that different countries respond differently to current economic volatility. Thus, it is important to determine how different countries adapt to global challenges. This research shows what economic effects were caused by the financial crisis of 2008 and the following recession in two economically cooperating countries: Lithuania and Ukraine. Ukraine is an important partner for Lithuania in two aspects: firstly, as a partner in foreign trade and, secondly, as a partner in foreign direct investment (FDI). Moreover, Ukraine is a significant partner for Lithuania, because it seeks to sign a Treaty of Association with the European Union (EU) and this should encourage tighter economic cooperation in the near future in the spheres of foreign trade and FDI.

The object of the article is the effects of economic recession after the financial crisis of 2008 in Lithuania and Ukraine.

The aim is to analyze the state of economy and the effects of recession and to compare the results in Lithuania and Ukraine in the conditions of globalization in the period of $2005-2011$. Objectives of the article are to investigate the economic cycles, their indicators and trends, to characterize economic effects of recession and compare these effects in Lithuania and Ukraine, to calculate the index of economic development as a part of sustainable development in conditions of globalization in these countries.

Research methods include scientific analysis of the sources, statistical data analysis.

\section{ECONOMIC CYCLES AND THEIR INDICATORS}

Global economic changes and fluctuations differently affect separate countries and the behaviour of their economic sectors. This effect is reflected in the main macroeconomic indicators of each country. Economic development is always associated with structural changes and economic fluctuations (recession, crisis, recovery or boom), which are described by the dynamics of economic indicators. The direction of indicators of a country's economy in different economic development stages of the cycle (recession, crisis, recovery or boom) are shown in Table 1. Economic/business cycle is a complex phenomenon which describes all economic fluctuations combining changes in all processes in the economy. Because of the active economic/business synchronisation factors, such as international trade, labour specialisation, foreign direct investment $[4 ; 6]$, economic status and its indicators can be analyzed and compared among individual countries. O. Blanchard, D. Quah [11] indicate that for the analysis of economic/business fluctuations, gross domestic product (GDP) and the changes of unemployment level need to be measured. C. Reinhart and K. Rogoff [13] warn that financial crises are typically long and very costly. Government initiated economic policy can mitigate economic volatility and lead to balanced and sustainable regional development in Lithuania and Ukraine. It is discussed in scientific literature which indicators are appropriate to be used to describe the development of coherence $[2 ; 3]$. One of the methods to study this process is to analyze, using World Bank data, the changes of such data as gross domestic product per capita (GDPpc) calculated in USD, foreign direct investment net inflows per capita (FDIpc) calculated in USD, employment rate (E) of the population aged $15+$ total in \%, real economic growth (EG) and unemployment rate level of population aged 15-64 years (UR) in \%, discomfort index in $\%$ (as the sum of unemployment and inflation rates (IR)), an interest rate (InR) in \%.

The changes of GDPpc in Lithuania show that the phase of recession has ended [14], but further recovery of economy and investment is necessary. FDI is one of the most important sources of capital formation. The analysis of statistical data shows that real GDP contracted in year 2009 in Lithuania was nearly $15.1 \%$ and in Ukraine $-15.0 \%$ (see Table 2). The change of real GDP in each country is directly related with the structure of its economic activities, e.g. the share of agriculture, industry and services in the whole economy. The agriculture value added as \% of GDP, according to Table 2, decreased in the period of 2005 - 2011 both in Lithuania and Ukraine, by $17.1 \%$ and $7.7 \%$, accordingly. Industry value added decreased in Lithuania by $14.3 \%$ and in Ukraine - by $1.9 \%$. The value added in services, calculated as \% of GDP, in Lithuania grew more 
intensively than in Ukraine. The value added in services in Lithuania grew throughout the entire period analyzed and achieved growth rate of $9.6 \%$ in 2011 . The value added in services in Ukraine grew only from 2008 and achieved $2.4 \%$ growth rate in 2011.

The ongoing contraction of economy increases the unemployment levels and decreases general price levels. An unemployed person loses all or a share of income, health insurance, some psychological issues arise and overall health is affected.

\section{TABLE I}

THE MAIN INDICATORS OF ECONOMIC/BUSINESS CYCLE AND THEIR CHANGING DIRECTIONS

\begin{tabular}{|l|l|l|l|l|}
\hline Indicator & Recession & Crisis & Recovery & Boom \\
\hline EG, GDPpc & Decreases & Low & Increases & High \\
\hline UR & Increases & High & Decreases & Low \\
\hline IR & Decreases & Low & Increases & High \\
\hline InR & Increases & High & Decreases & Low \\
\hline FDIpc & Decreases & Low & Decreases & High \\
\hline
\end{tabular}

A qualified and competent workforce is often a key factor in competitiveness, which increases the attractiveness of the region. Society both in Lithuania and in Ukraine, firstly, is aging and, secondly, faces an emigration problem, which results in a smaller number of workers, increasing numbers of the retired population, thus, greater attention should be paid to health and health care, in order to create preconditions for human capital development and labour supply expansion and improvement of regional competitiveness. The number of Lithuanian population decreased during the period of $2005-2011$ by $11.14 \%$, as shown in Table 3 . Particularly big diminish in population was observed in 2009-2010, when a number of population from $3.34 \mathrm{~m}$ diminished to $3.01 \mathrm{~m}$. The number of Ukrainian population decreased by $2.95 \%$ during the period of 2005-2011. The number of population fell accordingly from $47.1 \mathrm{~m}$. to $45.71 \mathrm{~m}$. The factors affecting the current conditions: demographic change, emigration, economic development, recession, rising of chronic disease rates and an epidemic global crisis; in the health sector - recurrent pandemic diseases (e.g., pandemic influenza A (H1N1), viral hepatitis, etc.) affect not only the country's economy and individual sectors, but also have a serious impact on the health status of the population. Health is an important investment and the engine of the country's socio-economic progress $[3 ; 16]$. Health status, education, and culture determine each employee's productivity, so the health of country's population is one of the most important elements of human capital, which must be developed. It is important to reduce the social exclusion of the health gap and poverty between different social groups, to encourage public participation in addressing health promotion issues.

TABLE II

THE MAIN INDICATORS OF ECONOMY AND ECONOMIC ACTIVITY IN LITHUANIA AND UKRAINE IN THE PERIOD 2005 - 2011, \% [15]

\begin{tabular}{|c|c|c|c|c|c|c|c|}
\hline Indicator/Year & 2005 & 2006 & 2007 & 2008 & 2009 & 2010 & 2011 \\
\hline \multicolumn{8}{|c|}{ 1.Real GDP growth rate (EG), \% } \\
\hline -Lithuania & 2.7 & 7.3 & 7.9 & 2.1 & -15.1 & 4.1 & 5.2 \\
\hline -Ukraine & 8.0 & 8.0 & 10.0 & 3.0 & -15.0 & 1.0 & 5.9 \\
\hline \multicolumn{8}{|c|}{ 2.Agriculture value added, $\%$ of GDP } \\
\hline -Lithuania & 4.8 & 4.3 & 3.9 & 3.7 & 3.4 & 3.5 & $\ldots$ \\
\hline --growth rate, $\%$ & 100.0 & 89.6 & 81.2 & 77.1 & 70.8 & 72.9 & $\ldots$ \\
\hline -Ukraine & 10.4 & 8.7 & 7.5 & 7.9 & 9.3 & 8.3 & 9.6 \\
\hline -- growth rate, $\%$ & 100.0 & 83.6 & 72.1 & 76.0 & 89.4 & 79.8 & 92.3 \\
\hline \multicolumn{8}{|c|}{ 3. Industry value added, $\%$ of GDP } \\
\hline -Lithuania & 32.9 & 32.9 & 32.6 & 31.6 & 26.9 & 28.2 & $\ldots$ \\
\hline --growth rate, $\%$ & 100.0 & 100.0 & 99.1 & 96.0 & 81.8 & 85.7 & $\ldots$ \\
\hline -Ukraine & 32.31 & 36.1 & 33.7 & 33.6 & 39.6 & 30.8 & 31.7 \\
\hline -- growth rate, $\%$ & 100.0 & 111.7 & 104.3 & 104.0 & 122.6 & 95.3 & 98.1 \\
\hline \multicolumn{8}{|c|}{ 4. Value added in services, $\%$ of GDP } \\
\hline -Lithuania & 62.3 & 62.8 & 63.5 & 64.7 & 69.7 & 68.3 & $\ldots$ \\
\hline --growth rate, $\%$ & 100.0 & 100.8 & 101.9 & 103.8 & 111.9 & 109.6 & $\ldots$ \\
\hline -Ukraine & 57.3 & 55.2 & 55.8 & 58.5 & 62.1 & 60.4 & 58.7 \\
\hline -- growth rate, $\%$ & 100.0 & 96.3 & 97.4 & 102.1 & 108.4 & 105.4 & 102.4 \\
\hline
\end{tabular}

The changes of GDPpc (calculated in USD) show that in Lithuania in year 2012 it reached GDPpc level, which was before the crisis of 2008. The changes of GDPpc in Ukraine in 2012 changed only slightly (by 1\%) and did not achieve the level of indicator before the crisis.
The changes of gross national income per capita calculated in purchasing power parity (in USD) (GNIpc (PPP)) in Lithuania show that in year 2011 it achieved the GNIpc (PPP) level, which was before the crisis. The level of GNIpc (PPP) of year 2008 in Ukraine was achieved in year 2012. This indicator, 
compared with GDPpc, is bigger because it shows that income from abroad both to Lithuania and to Ukraine is positive.

Unemployment rate in Lithuania after the crisis of 2008 fell significantly. The highest unemployment rate was 17.8 in 2010. The fall of unemployment level is related to the structural changes of economic activities, e.g. the fall of industry value added, in year 2008, as it was shown in Table 2 in Lithuania. The unemployment level in Ukraine is smaller in comparison with the unemployment level in Lithuania, because the industry value added is bigger in Ukraine and did not fall as significantly as it happened in Lithuania. Due to this reason, unemployment growth rate in Lithuania was bigger than in Ukraine and labour participation rate was smaller in Lithuania than in Ukraine. The number of employed persons in 2011 in Lithuania did not achieve the level before the crisis. The number of employed persons in 2011 in Ukraine diminished very slightly, by less than $1 \%$.

Present economic development is characterized by a prolonged economic depression [9], which is described by three waves:

1) the first wave - the economic impact, which is characterized by the reduced opportunities for economic development: firm bankruptcies, decrease of FDI net inflows, unemployment is a topical problem, especially among young people, changes in household income, which does not meet the wishes of consumers and their needs;

TABLE III

THE MAIN DEMOGRAPHIC, INCOME AND LABOUR MARKET INDICATORS IN LITHUANIA AND UKRAINE IN THE PERIOD 2005 - 2011, \% [15]

\begin{tabular}{|c|c|c|c|c|c|c|c|c|}
\hline Indicator/Year & 2005 & 2006 & 2007 & 2008 & 2009 & 2010 & 2011 & 2012 \\
\hline \multicolumn{9}{|l|}{ 1. Population, mill. } \\
\hline -Lithuania & 3.41 & 3.39 & 3.38 & 3.36 & 3.34 & 3.29 & 3.03 & 2.99 \\
\hline --changes rate, $\%$ & 100.0 & 97.77 & 99.12 & 98.53 & 97.95 & 96.48 & 88.86 & 87.68 \\
\hline -Ukraine & 47.1 & 46.79 & 46.51 & 46.26 & 46.05 & 45.87 & 45.71 & 45.59 \\
\hline -- changes rate, $\%$ & 100.0 & 99.34 & 98.75 & 98.22 & 97.77 & 97.39 & 97.05 & 96.79 \\
\hline \multicolumn{9}{|l|}{ 2. GDPpc,USD } \\
\hline -Lithuania & $7,604.0$ & $8,865.0$ & $11,584.2$ & $14,071.3$ & $11,033.6$ & $11,148.9$ & $14,154.6$ & $14,096.9$ \\
\hline --growth rate, $\%$ & 100.0 & 116.6 & 152.3 & 185.0 & 145.1 & 146.6 & 186.2 & 185.4 \\
\hline -Ukraine & 1828.7 & 2303.0 & 3068.6 & 3891.0 & 2545.5 & 2974.0 & 3575.5 & 3867.0 \\
\hline -- growth rate, $\%$ & 100.0 & 125.9 & 167.8 & 212.8 & 139.2 & 162.6 & 195.5 & 211.5 \\
\hline \multicolumn{9}{|c|}{ 3. GNIpc (PPP), USD } \\
\hline -Lithuania & 14050 & 15790 & 17580 & 19060 & 17390 & 17970 & 20760 & 22760 \\
\hline --growth rate, $\%$ & 100.0 & 112.4 & 125.1 & 135.7 & 123.8 & 127.9 & 147.8 & 162.0 \\
\hline -Ukraine & 5520 & 6130 & 6850 & 7250 & 6180 & 6590 & 7120 & 7300 \\
\hline -- growth rate, $\%$ & 100.0 & 111.0 & 124.1 & 131.3 & 112.0 & 119.4 & 129.0 & 132.2 \\
\hline \multicolumn{9}{|c|}{ 4. Unemployment rate, $\%$} \\
\hline -Lithuania & 8.3 & 5.6 & 4.3 & 5.8 & 13.7 & 17.8 & 15.4 & \\
\hline -Ukraine & 7.2 & 6.7 & 6 & 6 & 9.5 & 8 & 7.9 & \\
\hline \multicolumn{9}{|c|}{ 5. Unemployed persons, thous. } \\
\hline -Lithuania & 132.9 & 89.3 & 69.0 & 94.3 & 225.1 & 291.1 & 248.8 & \\
\hline --growth rate, \% & 100.0 & 67.19 & 51.92 & 70.96 & 169.38 & 219.04 & 187.21 & \\
\hline -Ukraine & 1623.3 & 1624.7 & 1395.6 & 1395.0 & 2095.2 & 1864.0 & 1864.8 & \\
\hline -- growth rate, $\%$ & 100.0 & 100.2 & 85.97 & 85.94 & 129.07 & 114.83 & 114.83 & \\
\hline \multicolumn{9}{|c|}{ 6.Labour participation rate, $\%$} \\
\hline -Lithuania & 56.6 & 55.9 & 56.3 & 56.7 & 57.8 & 58.2 & 58.6 & \\
\hline -Ukraine & 57.7 & 57.9 & 58.2 & 58.4 & 58.8 & 59.0 & 59.3 & \\
\hline \multicolumn{9}{|c|}{ 7. Employed persons, thous. } \\
\hline -Lithuania & 1473.9 & 1499.0 & 1534.2 & 1520.0 & 1415.9 & 1343.7 & 1370.9 & \\
\hline --growth rate, $\%$ & 100.0 & 101.7 & 104.1 & 103.1 & 96.1 & 91.2 & 93.0 & \\
\hline -Ukraine & 21570.0 & 21590.0 & 21860.0 & 21850.0 & 21180.0 & 21400.0 & 21410.0 & \\
\hline -- growth rate, $\%$ & 100.0 & 100.1 & 101.3 & 101.3 & 98.2 & 99.2 & 99.3 & \\
\hline
\end{tabular}

2) the second wave - the social impact (slow economic development returns to the previous level, high level of unemployment and stagnation), which is characterized by mental health problems, increasing tension and violence in families, predisposition to alcohol consumption and alcoholism, crime, and so on;

3 ) the third wave - speedy recovery, economic development goes back to its initial development trend, however, not all 
economic activities recover gradually, although the unemployment rate begins to decline, a part of the population is exposed to long-term problems: long-term unemployment, pessimism, chronic diseases, and so on.

In the current period, the effects of the second and third wave get manifested in both economic and social fields.

\section{ECONOMIC EFFECTS OF RECESSION}

In the scientific literature the effects of recession are classified using different criteria. M. Liefern, M. Shane define economic effects depending on the factors that have caused them [12]. According to [12], these factors can be direct (when the factors work inside the country) and indirect (when they work from outside of the country and depend on foreign trade, currency exchange and oil price changes in the international market). W.M. Liefern and M. Shane maintain that recession affects the structure of economic activity (agriculture, industry and services) differently depending on the time aspect (short time or long time) [12]. According to them, economic recession strongly affects the agricultural sector, but the impact on crop sector and livestock sectors differs. The increase of global demand for agricultural products is the reason why recession processes affected agricultural sector less, because the export of agricultural products was growing both in Lithuania and Ukraine. On the other hand, the stability of the agricultural sector development is based, in comparison with the industrial sector, on lower level of debt, both private and state. Some authors consider that the most important effect of crisis is the increase of poverty of the population and the reduction of expenditure of the households [1;8]. According to research of E.Baldacci, L.Mello, and G.Inchauste, about $60-70 \%$ of all negative consequences in the country economy occur due to four negative factors: unemployment, inflation, decreasing government spending and falling GDP. B. Gruževskis and R. Zabarauskaitè recommend analyzing such indicators as the employment level, incomes of population and level of life [7].
Recession, which causes the reduction of GDP, negatively affects the labour market. The unemployment rate in Lithuania increased to $17.8 \%$ in 2010 and was at a significant level in the year $2011-15.4 \%$, as shown in Table 3. The unemployment level in Lithuania in the analyzed period increased by $87.21 \%$. The unemployment level in Ukraine was less than in Lithuania, but overall increased to $14.83 \%$ in the period of $2005-2011$. The level of employed people decreased both in Lithuania and Ukraine, but it was bigger in Lithuania (7.0\%) than in Ukraine $(0.7 \%)$.

During the economic downturn, general supply exceeds aggregate demand and producers cannot sell their manufactured goods. General decline in demand is related to a fall in consumption, both private and public, fall in manufacture and unemployment growth [10].

After global financial crisis of 2008 and recession of 2012 the risk of poverty and exclusion is constantly increasing both in Lithuania and Ukraine. That negatively affects people's health and their ability to work, consequently, human capital and economic processes and performance diminish. Both present and future generations identify public health as the most important value in any value system. It determines the demographic future of the countries and their individual regions, as well as the future of the families: the amount of labour resources and the quality of future generation health.

The changes of poverty indicators are described by the Gini coefficient. The Gini coefficient, as it is shown in Table 4, dramatically increased in Lithuania since 2008 and in 2010 was $36.9 \%$, and in Ukraine - below 30\%. The level of population income inequality shows that the current economic and social policy is not efficient. The changes of Gini coefficient in Lithuania and Ukraine are compared with this index in EU-15 and EU-25. The comparison shows that poverty indices in EU-15 and EU-27 are significantly lower than in Lithuania.

TABLE IV

THE INCOME DIFFERENTIATION, GINI INDEX, INFLATION AND DISCOMFORT INDEX IN LITHUANIA AND UKRAINE IN THE PERIOD 2005-2011, \% [15]

\begin{tabular}{|c|c|c|c|c|c|c|c|}
\hline Economic Index/Year & 2005 & 2006 & 2007 & 2008 & 2009 & 2010 & 2011 \\
\hline \multicolumn{8}{|l|}{ 1.Gini index } \\
\hline -Lithuania & 36.3 & 35.0 & 33.8 & 34.0 & 35.5 & 36.9 & $\ldots$ \\
\hline -Ukraine & 29.0 & & & & 28.2 & 26.0 & $\ldots$ \\
\hline -ES-15 & 29.9 & 29.5 & 30.3 & 30.6 & 30.3 & 30.5 & $\ldots$ \\
\hline -ES-27 & 30.6 & 30.2 & 30.6 & 30.7 & 30.4 & 30.5 & $\ldots$ \\
\hline \multicolumn{8}{|c|}{ 2.Quantile income differentiation } \\
\hline -Lithuania & 6.9 & 6.3 & 5.9 & 5.9 & 6.3 & 7.3 & $\ldots$ \\
\hline -Ukraine & 5.8 & 6.5 & 6.3 & 5.5 & 5.2 & 4.9 & $\ldots$ \\
\hline -ES-15 & 4.8 & 4.7 & 4.9 & 4.9 & 4.9 & 5.0 & $\ldots$ \\
\hline$-\mathrm{ES}-27$ & 5.0 & 4.9 & 4.9 & 5.0 & 4.9 & 5.0 & $\ldots$ \\
\hline \multicolumn{8}{|l|}{ 3.Inflation } \\
\hline \multicolumn{8}{|l|}{ 3.1.CPI } \\
\hline -Lithuania & 2.6 & 3.7 & 5.7 & 10.9 & 4.4 & 1.3 & 4.1 \\
\hline -Ukraine & 13.6 & 9.1 & 12.8 & 25.2 & 15.9 & 9.4 & 8.0 \\
\hline
\end{tabular}




\begin{tabular}{|c|c|c|c|c|c|c|c|}
\hline \multicolumn{8}{|c|}{ 3.2.GDP defl. } \\
\hline -Lithuania & 6.6 & 6.5 & 8.5 & 9.8 & -3.7 & 2.8 & 5.2 \\
\hline -Ukraine & 24.6 & 14.9 & 22.8 & 28.6 & 13.1 & 13.7 & 14.4 \\
\hline \multicolumn{8}{|c|}{ 4.Disconfort index } \\
\hline -Lithuania & 14.9 & 12.1 & 12.8 & 15.6 & 17.4 & 20.6 & 20.6 \\
\hline -Ukraine & 31.8 & 21.6 & 28.8 & 34.6 & 22.6 & 21.7 & 22.3 \\
\hline
\end{tabular}

In Lithuania the income differentiation after economic crisis dramatically increased from 5.9 in year 2008 to 7.3 in 2010. In Ukraine this indicator decreased from 5.5 to 4.9 during the same period, it shows positive economic and social policy changes in the post-crisis period.

Inflation measured as CPI in Lithuania both before the economic crisis and after it was less than in Ukraine. It is important that inflation measured as GDP deflator in Lithuania was less than in Ukraine, too. It means that the price level for both constant consumer basket goods and for all goods and services produced in the country during the period of 2005-2011 was less in Lithuania than in Ukraine.

The discomfort index increased in Lithuania after financial crisis of 2008 from $15.6 \%$ to $20.6 \%$. In Lithuania this growth was mainly caused by unemployment growth. The discomfort index decreased in Ukraine from $34.6 \%$ in year 2008 to $22.3 \%$ in year 2011.

\section{INDEX OF ECONOMIC DEVELOPMENT}

Based on the given analysis of the main macroeconomic indicators, we determine what is achieved in economic development in Lithuania and Ukraine. Year 2005 was chosen as a base year for the evaluation of the economic development index in Lithuania and Ukraine in the period of 2005-2011 (the index of economic development in year 2005 is equal to $100.0 \%$ ), as it is shown in Table 5. This index characterizes the economic development of a country, evaluating the changes of three described macroeconomic indicators: GDPpc (measured in USD), FDIpc (measured in USD) and employment index (measured in \%).

Due to the lack of information, it is problematic to define the share of each economic indicator included in this index and the method of equal base weights is used. Evaluating economic development, only the indicators the increase of which has a positive effect on the economic development (GDPpc, FDIpc and employment index) are taken into calculation.

The economic development index $\left(I_{\mathrm{DV}}\right)$ is evaluated according to formula (1):

$$
I_{D V}=\sum_{i=1}^{n} a_{i} \times I_{i} \text {, }
$$

where $a_{\mathrm{i}}$ - is the weight of a separate element of economic development index. The condition (formula 2), which is valid for all the weights of all elements of economic development indexes:

$\sum_{i=1}^{n} a_{i}=1$, where: $I_{\mathrm{i}}$ is the element of economic development index. We use three indexes: index of GDPpc $\left(I_{\mathrm{GDP}}\right)$, index of FDIpc $\left(I_{\mathrm{FDI}}\right)$ and index of employment $I_{\mathrm{E}}$. The economic development index includes three aspects of economic development: GDPpc, FDIpc and employment index, described in formula (3):

$I_{D V}=a_{1} \times I_{G D P}+a_{2} \times I_{F D I}+a_{3} \times I_{E}$,

The index of economic development both in Lithuania and Ukraine in the period of 2005-2008 had grown, but in the period of 2009-2011 the growth was less than in year 2008. Calculated index of economic development in Lithuania was $133.92 \%$ and in Ukraine $-124.16 \%$ in year 2008. Lithuania and Ukraine did not achieve the level of economic development of year 2008 in year 2011, because this index in these countries was $125.78 \%$ and $107.78 \%$, accordingly. These processes were caused by the contraction of GDP and FDI inflows into industry and agricultural sectors.

\section{CONCLUSION}

Research shows that the financial crisis differently affects the changes of economic indicators in Lithuania and Ukraine. In each country the global crisis reduced aggregate demand and demand for labour force, due to this emigration increased and the number of population decreased. Real GDP contraction in year 2009 in Lithuania was nearly $15.1 \%$ and in Ukraine $-15.0 \%$.

Unemployment level significantly increased in Lithuania and in 2010 was $17.8 \%$, it reduced in year 2011 to $15.4 \%$. Unemployment level in Ukraine in 2009 was the highest and reached up to $9.5 \%$, but in the current period it is $8 \%$.

The inflation level evaluated in CPI both in Lithuania and Ukraine was the biggest in year 2008, $10.8 \%$ and $25.2 \%$, respectively. Inflation level evaluated as GDP deflator both in Lithuania and Ukraine was the highest in year 2008, 9.8\% and $28.6 \%$, accordingly.

The Gini coefficient dramatically increased in Lithuania since 2008 and in 2010 was $36.9 \%$, and in Ukraine - below $30 \%$.

The economic development index includes three aspects of economic development: GDPpc, FDIpc and employment level in the country, which are calculated as corresponding indexes. All these structural elements of economic development index are equally important and none of them has a priority in comparison with others. It would be preferable if the growth rate of all of these structural elements of economic development index was the same.

The calculated index of economic development in Lithuania was $133.92 \%$ and in Ukraine - $124.16 \%$ in year 2008. Lithuania and Ukraine did not achieve the level of economic development of year 2008 in year 2011, because this index in these countries was $125.78 \%$ and $107.78 \%$, accordingly. 
In future perspective, the main problem for the Lithuanian economic development is industry policy, which significantly affects the growth of employment level and increase of value added of industry. Considering future economic development of Ukraine, the main problem is increasing price levels, which are related not only with CPI, but with significant level of GDPdefl as well. High level of GDPdefl shows, that the price level will grow in the future, both for consumer and investment goods and services. Such situation in Lithuanian and Ukraine conditions the necessity to develop a strategic industry and economic policy, both fiscal and monetary.

TABLE V

THE STRUCTURE AND INDEX OF ECONOMIC DEVELOPMENT IN LITHUANIA AND UKRAINE IN THE PERIOD 2005 - 2011, \% [15]

\begin{tabular}{|c|c|c|c|c|c|c|c|}
\hline Indicators/Year & 2005 & 2006 & 2007 & 2008 & 2009 & 2010 & 2011 \\
\hline \multicolumn{8}{|l|}{ 1. GDPpc, $\%$} \\
\hline -Lithuania & 33.4 & 37.47 & 41.72 & 45.23 & 41.27 & 42.66 & 49.26 \\
\hline -Ukraine & 33.4 & 37.02 & 41.37 & 43.89 & 37.33 & 39.8 & 43.0 \\
\hline \multicolumn{8}{|l|}{ 2. FDIpc, $\%$} \\
\hline -Lithuania & 33.3 & 57.86 & 65.81 & 54.79 & 0.55 & 25.1 & 45.52 \\
\hline -Ukraine & 33.3 & 24.08 & 44.06 & 46.51 & 20.82 & 28.28 & 31.7 \\
\hline \multicolumn{8}{|c|}{ 3. Employment index, $\%$} \\
\hline -Lithuania & 33.3 & 33.9 & 34.7 & 34.4 & 32.02 & 30.39 & 31.0 \\
\hline -Ukraine & 33.3 & 33.36 & 33.78 & 33.76 & 32.73 & 33.07 & 33.08 \\
\hline \multicolumn{8}{|c|}{ 4. Index of economic development, $\%$} \\
\hline -Lithuania & 100.0 & 129.23 & 142.23 & 133.92 & 73.84 & 98.15 & 125.78 \\
\hline -Ukraine & 100.0 & 94.46 & 119.21 & 124.16 & 90.88 & 101.15 & 107.78 \\
\hline
\end{tabular}

\section{REFERENCES}

1. Baldacci, E., De Mello, L., Inchauste, G. Financial Crisis, Poverty and Income Distribution. IMF Working Paper 02/04 Washington: International Monetary Fund, 2002. 48 p.

2. Čiegis R., Ramanauskienè, J., Šimanskienè, L. Lietuvos regiono darnaus vystymosi vertinimas. Klaipèda: Klaipèdos universiteto leidykla, 2010. $124 \mathrm{p}$.

3. 2010. Europe 2020. A Strategy for smart, sustainable and inclusive growth. COM (2010). European Commission, 2010- [Accessed 10.09.2013.]. Available: http://eur-lex.europa.eu/LexUriServ/LexUri Serv.do?uri=COM:2020:2020:FIN:EN:PDF.

4. Davis, S. Globalization and Business cycle. Doctoral Dissertation. Tennessee: Vanderbilt University, 2009.

5. Employment and Social Development: growing divergence and higher risks of long-term exclusion, 2013 - [Accessed 10.09.2013.]. Available: http://europa.eu/rapid/press-release_IP-13-5_en.htm.

6. Farhat, D. F. On the transmission Mechanism of International Business Cycles. Doctoral Dissertation. California: University of California, 2009.

7. Gruževskis, B., Zabarauskaite, R. Social Consequences of the Economic downturn in Lithuania. Social development of Lithuania, 2012, Nr. 1, p. $5-22$.

8. Jones C. I. Macroeconomics. Economics Crisis Update. New York, London: W.W.Norton\&Company, 2010. 496 p.

9. Cabinet Office Social Exclusion task Force. Learning from the past: Working together to tackle the social consequences of recession, 2009 [Accessed 10.09.2013.]. Available:

http://www.sciesocialcareonline.org.uk/searchpasp?query=author $=\% 22$ GREAT\%20BRITAIN.\%20Cabinet\%20Office\%20social\%20Exclusion\% 20Task $\$ 20$ Forceorce $\% 22$.

10. Palley, T. I. From Financial Crisis to Stagnation. The Destruction of Shared Prosperity and the Role of Economics. London: Cambridge University Press, 2012, 238 p. http://dx.doi.org/10.1017/CBO9781139061285

11. Blanchard, O. Quah, D The dynamic Effects of aggregate Supply and Demand Disturbances. American Economic Review, 1989, 793.

12. Liefern, W. M., Shane, M. The World Economic Crisis and U.S. Agriculture: from Boom to Gloom? A Publication of the Agricultural \& Applied Economics Association (AAEA). CHOICES. The Magazine of Food, Farm and Resource Issues, 2009, No. 24(1), p. 22-26.

13. Reinhart, C., Rogoff, K. The Aftermath of Financial Crises. Harvard University working paper, December, 2008.
14. „Swedbank“ makroekonomikos apžvalga. Nuosmukis baigèsi. Ekonomikos apžvalga: Lietuva. 2011 - [Accessed 10.09.2013.]. Available: http://www.swedbank.1t/lt/previews/get/2156/1294996753_Swedbank_E konomikos_apzvalga_Lietuva_\%28_2011_m._sausis.\%29.pdf

15. The World Bank Group Data. World Bank Data. World development Indicators, 2013 - [Accessed 10.09.2013.]. Available: http://www.databank.worldbank.org/data/views/reports/tablview.aspx

16. Ciburiene, J. Ciburaite, G. Ekonomičeskoe pazvinie i izmenenija politiki zdrabooxpanenija v uslovijax globalizacii: Litovskij opyt. V: Sbornik nayčnyx trudov. Problemy i perspektivy pazvitija sotrudničestva meždu stpanami Jugo-Vostočnoj Evropy b ramkax Černomorckogo ekonomičeskogo cotrudničestva i GUAM, Postov-na-Dony - Doneck, Rosija - Ukraina, Sentiabr 12-14, 2013, str. 490-494.

Jadvyga Ciburiene graduated from Kaunas Polytechnic Institute (at present Kaunas University of Technology, KTU) in 1979. PhD degree in social sciences (economics, S 04) was earned in 1992, associate professor of Economics and International Trade Department of KTU since 1992. Habilitation procedure was carried out in 2006 and since 2006 she has been Professor of social science (economics S 04). The title of Professor was awarded in 2008.

Major fields of study: macroeconomics theory, international economics and trade. Work experience in higher education: 30 years at KTU. Besides pedagogical work prof. Jadvyga Ciburiene has a two year practical work experience as an engineer-economist. She has more than 140 publications, including 2 monographs and more than 120 scientific articles, 40 of them in the publications of other states, 4 textbooks, 1 scientific study and 2 study books. She actively participates in the development of Lithuanian Encyclopedia.

Address: Laisves Av. 55 - 506, Faculty of Economics and Management, KTU, Kaunas, Lithuania, LT - 44309.

Telephone and e-mail adress: +370 300576, jadvyga.ciburiene@ktu.lt

Tatiana Orekhova graduated from the Donetsk State University in 1994. PhD degree in economics was earned in 1999, Associate Professor of International Economics Department of the Donetsk National University since 2001, Doctor of Economics from 2008, Professor of International Economics since 2009. Major fields of study: international economics and corporate social responsibility.

Work experience in higher education - 18 years at the Donetsk National University. 
Professor Tatiana Orekhova is the head of International Business and Applied Economics Department, Donetsk National University, also the Vice-Dean of the Faculty of Economics of the Donetsk National University.

She has more than 120 publications, including 12 monographs and more than 80 scientific articles, 21 of them - in the leading publications of other states, 4 manuals and 1 textbook approved by the Ministry of Education and Science of Ukraine.

Jadvyga Ciburiene, Tatiana Orekhova. Recesijas sekas: Lietuvas un Ukrainas pieredze. Pasaules finanšu krīze, kas sākās 2008. gadā un satricināja visas valstis, radīja dziḷu ekonomisku lejupslīdi. Ilgstošāe ekonomiskā lejupslīde paaugstināja bezdarba līmeni un palielināja iedzīvotāju nabadzību.

Rakstā izanalizētas ekonomiskās sekas, kuras radīja 2008. gada finanšu krīze un tai sekojošā recesija divās valstīs, kas ekonomiski sadarbojas savā starpā - Lietuvāa un Ukrainā. Ukraina ir nozīmīgs Lietuvas ekonomiskās sadarbības partneris divu aspektu dēḷ - pirmkārt, kā iekšējas tirdzniecības partneris, otrkārt, kā partneris ārvalstu kapitāla investīiju jomā.

Pētījuma mērkis: izanalizēt ekonomisko situāciju laika periodā no 2005. līdz 2011. gadam; noskaidrot recesijas sekas Lietuvā un Ukrainā un salīizzināt tās. Pētījuma galvenie uzdevumi: aplūkot ekonomisko ciklu rādītājus, kas raksturo recesijas sekas un salīdzināt recesijas ietekmi Lietuvā un Ukrainā, aprēḳināt ekonomiskās attīstības indeksu kā šo valstu ilgtspējīgas attīstības sastāvdaḷu. Aprēḳinos kā bāzes vērtība pieṇemti 2005. gada rādītāji.

Pētījumi rāda, ka finanšu krīze samazināja iekšzemes pieprasījumu pēc darbaspēka, kas radīja emigrācijas vilni, kā rezultātā samazinājās iedzīvotāju skaits. Lietuvā bezdarba līmenis palielinājās daudz ievērojamāk nekā Ukrainā, savukārt inflācijas līmenis Ukrainā bija gandrīz divas reizes lielāks nekā Lietuvā. Bezdarba un inflācijas dilemmas risinājums lielā mērā ir atkarīgs no katras valsts ekonomiskās politikas.

Pẹtījuma metodes: avotu zinātniskā analīze; Pasaules bankas datu statistiskā analīze, kas balstās uz pirktspējas paritātes novērtējumu.

Ядвига Чибурене, Татьяна Орехова. Эффекты спада: литовский и украинский пример. Страны мира испытали глубокий экономический спад после начавшегося в 2008 году мирового финансового кризиса. Продолжающееся сокращение экономики увеличивало уровень безработицы и бедность населения.

В настоящей статье проанализированы экономические последствия, вызванные финансовым кризисом 2008 года и последующей за ним рецессией в двух экономически сотрудничающих странах: в Литве и в Украине. Украина является важным партнером экономического сотрудничества Литвы в двух аспектах: во-первых, в качестве партнера в области внешней торговли и, во-вторых, в качестве партнера в области прямых иностранных инвестиций. Цель: проанализировать состояние экономики в период 2005-2011 г., выявить эффекты рецессии в Литве и в Украине и сравнить их. Главные задачи: рассмотреть экономические показатели экономических циклов, характеризующие экономические последствия рецессии и сравнить эти эффекты в Литве и Украине, рассчитать индекс экономического развития в рамках сбалансированного развития в этих странах. В расчетах 2005 год выбран в качестве базового года.

Исследования показывают, что финансовый кризис по-разному влияет на изменения экономических показателей в Литве и Украине. В каждой стране мировой кризис уменьшил совокупный спрос и спрос на рабочую силу, в связи с этим увеличилась эмиграция, и количество населения уменьшилось. Уровень безработицы в Литве увеличился более значительно, чем в Украине, но уровень инфляции почти в два раза больше в Украине, чем в Литве. Дилема безработицы и инфляции в значительной мере зависит от экономической политики каждой страны.

Методы исследования: научный анализ источников, статистический анализ данных Всемирного банка, оценивающихся по паритету покупательной способности.

This research was funded by a grant (No. TAP LU 09/2012) from the Reseach Council of Lithuania. 